\title{
Halogenated Ring Carcinogen
}

National Cancer Institute

\section{Source}

National Cancer Institute. Halogenated Ring Carcinogen. NCI Thesaurus. Code C45186.

A cyclic compound in which at least one hydrogen is replaced by a halogen (chlorine,

bromine, iodine, fluorine, astatine) and exposure to this compound can increase the risk human cancer. (NCI05) 